\title{
Metode Tongkat Berbicara (Talking Stick) dalam Pembelajaran Keterampilan Berbicara Menanggapi Cerita Pendek
}

\author{
Mawar Sri Wulan Br. Sibuea ${ }^{1}$ dan Dian Syahfitri ${ }^{2}$ \\ 1,2 Universitas Prima Indonesia
}

\begin{tabular}{l}
\hline \hline Keywords: \\
Implementation; \\
Speech Skills; \\
Responding to Short Stories; \\
Stick Talking
\end{tabular}

Kata kunci:

Penerapan;

Keterampilan Berbicara;

Menanggapi Cerpen;

Tongkat Berbicara

\begin{abstract}
This study aims to describe the improvement of speech skills in responding to students' short stories through the application of the stick talking method. This study is based on learning to speak in response to the short story on the students in the category of low. The method used in this study is qualitative descriptive with a classroom action approach that describes speaking skills to respond to classical short stories and speaking skills in response to a short story through a talking stick method. in practive both two cycles consisting of the planning stage, the execution of the action, the observation, and the reflection. The subject of this study were samples dran bypurposive sampling technique of 30 students of class VII-C SMP Negeri 40 Medan. The results showed that students 'ability to respond to the students' short story increased after talking stick method was applied in the pre-cycles, the average score was 52.33 and the percentage of classical completeness was $20 \%$ After applying the method of talking stick ), the result of the students 'test scores on the first cycle obtained an average score of 69.5 and increased to 71.67 in the second cycle test.Based on the percentage of students' classical completeness in cycle I $66.67 \%$ increase in cycle II $76.67 \%$. The research concluded that the application of talking stick method can improve the speaking skill in responding to the short story in the students of class VII-C SMP Negeri 40 Medan.
\end{abstract}

\begin{abstract}
Abstrak: Penelitian ini bertujuan untuk mendeskripsikan peningkatan keterampilan berbicara dalam menanggapi cerpen siswa melalui penerapan metode tongkat berbicara (talking stick). Pelaksanaan penelitian ini berdasarkan permasalahan yang ada pada pembelajaran berbicara dalam menanggapi cerpen pada siswa yang masih tergolong rendah. Metode yang digunakan dalam penelitian ini adalah kualitatif deskriptif dengan pendekatan tindakan kelas yang mendeskripsikan keterampilan berbicara dalam menanggapi cerpen pada siswa secara klasikal dan keterampilan berbicara dalam menanggapi cerpen melalui metode tongkat berbicara (talking stick) dalam bentuk pelaksaannya dua siklus yang terdiri dari tahap perencanaan, pelaksanaan tindakan, pengamatan, dan refleksi. Subjek penelitian ini dilakukan dengan sampel bertujuan (purposive sample) pada 30 siswa kelas VII-C SMP Negeri 40 Medan. Hasil penelitian menunjukkan keterampilan berbicara dalam menanggapi cerpen siswa meningkat setelah menerapkan metode tongkat berbicara (talking stick). Pada pembelajaran prasiklus siswa memperoleh nilai rata-rata 52,33 dan persentase ketuntasan klasikal 20\%. Setelah menerapkan metode tongkat berbicara (talking stick), hasil penilaian tes siswa pada siklus I memperoleh nilai rata-rata 69,5 dan meningkat menjadi 71,67 pada tes siklus II. Dilihat dari persentase ketuntasan klasikal siswa pada siklus I 66,67\% meningkat pada siklus II 76,67\%. Sehingga penelitian ini dapat disimpulkan bahwa penerapan metode tongkat berbicara (talking stick) dapat meningkatkan keterampilan berbicara dalam menanggapi cerpen pada siswa kelas VII-C SMP Negeri 40 Medan.
\end{abstract}

\section{Alamat Korespondensi:}

E-mail: mawarsri1995@gmail.com (Mawar Sri Wulan Br. Sibuea)

\section{Pendahuluan}

Keterampilan berbahasa mempunyai empat komponen, yaitu keterampilan menyimak, berbicara, membaca, dan menulis. Salah satu keterampilan berbahasa yang dapat menjadi sarana komunikasi serta 
mengungkapkan ide kepada orang lain dan mampu meningkatkan kemampuan berbahasa terhadap peserta didik adalah keterampilan berbicara. Dengan keterampilan berbicara, peserta didik mampu menyampaikan informasi serta mengungkapkan gagasan dalam bentuk lisan dengan menggunakan cara berpikir yang kreatif.

Dalam mata pelajaran Bahasa Indonesia, keterampilan berbicara merupakan salah satu kompetensi dasar yang menjadi bagian dalam standar kompetensi kemampuan berbahasa. Standar kompetensi menanggapi cerpen pada silabus Bahasa Indonesia kelas VII yaitu mengungkapkan tanggapan terhadap pembacaan cerpen. Melalui kegiatan berbicara peserta didik diharapkan mampu mengungkapkan pikiran, gagasan, dan perasaan dalam bentuk lisan tentang suatu peristiwa atau masalah.

Berdasarkan hasil observasi dan wawancara peneliti dengan guru Bahasa Indonesia yang mengajar di sekolah tersebut, siswa kurang memahami dalam pembelajaran menanggapi cerpen. Terdapat standar hasil dari pembelajaran ini belum begitu memuaskan. Nilai KKM yang ditentukan sekolah adalah 70. Hanya 50\% yang dapat memenuhi target yang telah ditetapkan. Artinya, ada sekitar 50\% siswa yang belum mencapai nilai KKM, karena hanya mendapatkan nilai rata-rata 60. Berdasarkan ini peneliti mencoba membantu dan turut bekerja sama kepada guru yang bersangkutan dalam membina pengajaran Bahasa Indonesia khususnya pembelajaran menanggapi cerpen.

Hal ini sesuai dengan hasil observasi dengan guru dan siswa kelas VII-C SMP pada tanggal 5 Januari 2017, ditemukan beberapa permasalahan dalam keterampilan berbicara dalam menanggapi cerpen, yaitu (1) kurangnya penguasaan kosakata siswa dalam menanggapi cerpen, (2) kurang berminatnya siswa dalam pembelajaran menanggapi cerpen, (3) siswa masih kesulitan dalam mengungkapkan ide-ide, gagasan, dan pikirannya dalam bentuk lisan, (4) metode yang digunakan guru masih belum tepat dengan pembelajaran menanggapi cerpen.

Berdasarkan permasalahan tersebut, pembelajaran memerlukan metode yang menarik untuk mendukung berlangsungnya proses pembelajaran. Dalam proses pembelajaran guru sangat berperan penting terhadap keberhasilan menanggapi cerpen. Guru harus memotivasi peserta didik dalam proses pembelajaran, serta mampu memilih metode yang tepat untuk pembelajaran menanggapi cerpen agar peserta didik tidak merasa bosan dan jenuh.

Upaya yang dapat dilakukan untuk memperbaiki hasil pembelajaran dengan memilih metode pembelajaran yang digunakan untuk meningkatkan keterampilan berbicara siswa adalah metode tongkat berbicara (talking stick). Kurniasih dan Sani (2015 : 82) menyatakan bahwa, tongkat berbicara (talking stick) merupakan metode pembelajaran kooperatif yang dilakukan dengan bantuan tongkat sebagai alat untuk mendapatkan giliran untuk berpendapat atau menjawab pertanyaan dari guru setelah siswa mempelajari materi pembelajaran.

Dalam metode ini, dapat memudahkan siswa dalam belajar memahami materi pelajaran dan menjadikan proses pembelajaran tidak membosankan. Akan tetapi, pembelajaran tersebut akan menjadi pembelajaran yang menyenangkan dan menarik bagi siswa. Metode ini memiliki karakteristik secara aktif, kreatif, efektif, interaktif, dan menyenangkan bagi siswa sehingga konsep mudah dipahami dan bertahan lama dalam struktur kognitif siswa. Jadi, dengan menggunakan metode talking stick ini, diharapkan dapat meningkatkan keterampilan berbicara menanggapi cerpen.

Berdasarkan pemaparan tersebut, peneliti akan mengkaji "Penerapan Metode Tongkat Berbicara (Talking Stick) untuk Meningkatkan Keterampilan Berbicara dalam Menanggapi Cerita Pendek pada Siswa Kelas VII-C SMP Negeri 40 Medan Tahun Pelajaran 2016/2017".

\section{Metode}

Penelitian ini dilaksanakan di SMP Negeri 40 Medan pada kelas VII-C Tahun Pelajaran 2016/2017 Klambir Lima, kec. Medan Helvetia, kel. Tanjung Gusta. Pemilihan lokasi ini berdasarkan atas beberapa pertimbangan bahwa di sekolah tersebut terdapat permasalahan pembelajaran harus diselesaikan dan dicari pokok permasalahannya. Oleh karena itu, peneliti melakukan penelitian di SMP Negeri 40 Medan, kelas VII-C. Alasan memilih lokasi penelitian tersebut, yaitu:

a. Di sekolah tersebut belum pernah dilaksanakan penelitian berjudul "Penerapan Metode Tongkat Berbicara (Talking Stick) untuk Meningkatkan Keterampilan Berbicara Menanggapi Cerpen Pada Siswa Kelas VII-C SMP Negeri 40 Medan.

b. Di sekolah tersebut cukup mewakili dalam pengambilan data.

c. Keterampilan dalam pembelajaran Bahasa Indonesia siswa, khususnya keterampilan berbicara masih perlu ditingkatkan.

d. Jarak lokasi penelitian tidak jauh dari rumah. 
Penelitian ini diawali dengan tahap identifikasi masalah, pengajuan judul, penyusunan proposal sampai pada hasil penelitian. Waktu penelitian ini merupakan rincian kegiatan yang dilakukan untuk memenuhi syarat dan memperoleh gelar sarjana pendidikan. Penelitian ini dimulai dari Mei 2017 dan diperkirakan selesai pada bulan Juli 2017.

Berdasarkan hal tersebut pendekatan yang digunakan dalam penelitian adalah pendekatan kualitatif dengan metode PTK yang merupakan jenis penelitian didasarkan atas data deskriptif dari setiap individu berupa sikap dan perilaku bisa diamati selama proses pembelajaran berlangsung. Menurut Sugiyono (2014: 3) mengatakan bahwa "Pendekatan penelitian merupakan cara ilmiah untuk mendapatkan data dengan tujuan dan kegunaan tertentu. Penelitian ini dilakukan dengan menggunakan pendekatan Penelitian Tindakan Kelas (PTK)". Menurut Arikunto (2013: 128) mengatakan bahwa kirakira sepuluh tahun yang lalu, muncul pendekatan penelitian yang langsung menjadi terkenal.

Menurut Kemmis (dalam Subyantoro, 2009: 8) "Penelitian tindakan kelas sebagai suatu bentuk penelahaan atau inkuiri melalui refleksi diri yang dilakukan oleh peserta kegiatan pendidikan tertentu dalam situasi sosial". Sedangkan menurut Subyantoro (2009: 8) mengatakan bahwa penelitian tindakan kelas merupakan suatu bentuk kajian reflektif oleh pelaku tindakan yang dilakukan untuk meningkatkan kemantapan rasional dari tindakan mereka dalam melaksanakan tugas, memperdalam pemahaman terhadap tindakan-tindakan yang dilakukan, serta memperbaiki kondisi dimana praktek pembelajaran tersebut dilakukan.

Teknik pengumpulan data yang dilakukan pada penelitian tindakan kelas ini diambil dengan beberapa teknik diantaranya dengan menggunakan observasi, wawancara, tes, dokumentasi. Teknik analisis data digunakan dalam penelitian tindakan kelas ini menggunakan teknik analisis deskriptif kualitatif. Analisis data ini dilakukan dengan kolaboratif antara peneliti dan guru Bahasa Indonesia berdasarkan reflektif dari data yang terkumpul. Teknik analisis data kualitatif dalam penelitian ini digunakan untuk menganalisis data-data yang berupa hasil observasi, dokumentasi tugas siswa. Langkahlangkah yang ditempuh dalam deskriptif kualitatif adalah sebagai berikut.

1. Perbandingan antar data, yaitu membandingkan data-data dari setiap informasi yang diperoleh untuk memudahkan dalam mengklasifikasi data yang sama.

2. Kategorisasi, yaitu mengelompokkan data-data ke dalam kategori tertentu.

3. Penyajian data dalam bentuk tabel dan diagram.

4. Menarik kesimpulan secara induktif, yaitu data yang sudah dikelompokkan dibuat penafsiran sehingga dapat diperoleh kesimpulan.

Sesuai dengan karakteristik penelitian tindakan, keberhasilan penelitian tindakan ini ditandai adanya perubahan ke arah perbaikan. Indikator keberhasilan dapat ditentukan berdasarkan proses dan produk.

1. Indikator Keberhasilan Proses

a. Proses pembelajaran dilaksanakan secara menarik dan menyenangkan.

b. Siswa aktif berpartisipasi dalam proses pembelajaran keterampilan berbicara dalam menanggapi cerpen.

c. Siswa mampu memahami pembelajaran keterampilan berbicara dalam menanggapi cerpen menggunakan metode tongkat berbicara (talking stick).

2. Indikator Keberhasilan Produk

Indikator keberhasilan produk dideskripsikan dari keberhasilan siswa dalam praktik berbicara dalam menanggapi cerpen dengan metode tongkat berbicara (talking stick). Keberhasilan produk diperoleh apabila nilai KKK 75\% siswa kelas VII-C SMP Negeri 40 Medan mendapatkan nilai KKM 70 setelah diberikan tindakan.

\section{Hasil dan Pembahasan}

\section{Hasil Penelitian}

Penelitian dilaksanakan di kelas VII-C SMP Negeri 40 Medan dengan jumlah 30 siswa yang terdiri dari 14 siswa laki-laki dan 16 siswa perempuan. Hasil penelitian ini diperoleh dari hasil tindakan prasiklus, siklus I dan siklus II yang terdapat pada hasil tes dan nontes. Hasil tes prasiklus merupakan hasil sebelum menerapkan metode tongkat berbicara (talking stick) dalam keterampilan berbicara dalam menanggapi cerpen pada tindakan siklus I. Selanjutnya hasil tes tindakan siklus I dan II merupakan hasil keterampilan berbicara menanggapi cerpen sesudah menerapkan metode tongkat berbicara (talking stick). Kemudian pada hasil nontes terdapat data observasi dan dokumentasi berupa foto, data sekolah, dan data siswa pada saat berlangsungnya proses pembelajaran Bahasa Indonesia khususnya keterampilan berbicara di kelas. 
Adapun hasil penelitian ini mencakup tiga hal berikut 1) Kualitas proses pembelajaran keterampilan berbicara dalam menanggapi cerita pendek dengan menggunakan metode tongkat berbicara (talking stick) pada siswa kelas VII-C SMP Negeri 40 Medan; 2) Kualitas hasil pembelajaran keterampilan berbicara dalam menanggapi cerita pendek dengan menggunakan metode tongkat berbicara (talking stick) pada siswa kelas VII-C SMP Negeri 40 Medan; 3) Peningkatan hasil pembelajaran keterampilan berbicara dalam menanggapi cerita pendek dengan menggunakan metode tongkat berbicara (talking stick) pada siswa kelas VII-C SMP Negeri 40 Medan.

Kualitas proses pembelajaran keterampilan berbicara dalam menanggapi cerita pendek dengan menggunakan metode tongkat berbicara (talking stick) pada siswa kelas VII-C SMP Negeri 40 Medan tahap prasiklus ini merupakan tindakan yang paling awal dilakukan tanpa melakukan tindakan pembelajaran dengan menggunakan metode yang ingin diterapkan. Hal ini dilakukan untuk mengetahui kondisi awal subjek penelitian dan nilai hasil belajar siswa pada pembelajaran berbicara sebelum melakukan tindakan. Hasil analisis dari tindakan pembelajaran prasiklus akan dijadikan sebagai refleksi bagi peneliti agar dapat memperbaikinya pada saat memasuki tindakan siklus pembelajaran selanjutnya.

\section{Pembahasan}

Adapun deskripsi hasil kegiatan pembelajaran pada prasiklus, kegiatan prasiklus dimulai dengan mengajarkan materi menanggapi cerpen secara singkat dan langsung memberikan soal-soal tes awal keterampilan berbicara dalam menangggapi cerpen prasiklus. Tes ini diberikan kepada siswa kelas VII-C SMP Negeri 40 Medan sebagai subjek penelitian yang berjumlah 30 siswa.

Tahapan tindakan pembelajaran siklus I merupakan tindakan awal untuk memperbaiki permasalahan yang terdapat di kelas yaitu rendahnya keterampilan berbicara dalam menanggapi cerita pendek siswa kelas VII-C SMP Negeri 40 Medan. Pembelajaran siklus I yang berperan sebagai guru dalam menyampaikan materi pembelajaran adalah peneliti. Dalam proses pembelajaran di siklus I ini, siswa lebih berperan aktif untuk berbicara dalam menanggapi cerpen yang berjudul "Perjuangan Nisa". Peneliti beraktivitas sebagai guru mengajak siswa untuk berbicara dalam menanggapi cerpen. Siswa harus berkonsentrasi dan fokus untuk menyiapkan jawaban ataupun tanggapan yang akan diberikan.

Peneliti bersama guru mata pelajaran Bahasa Indonesia adalah menerapkan pembelajaran dengan menggunakan metode tongkat berbicara (talking stick) berdasarkan RPP yang telah direncanakan dan dibuat sesuai metode untuk digunakan di tempat penelitian yaitu kelas VII-C SMP Negeri 40 Medan. Peneliti menyampaikan tujuan pembelajaran (kompetensi dasar) yang ingin dicapai pada akhir proses pembelajaran khususnya metode tongkat berbicara (talking stick), dan menjelaskan langkah-langkah kegiatan pembelajaran dengan menggunakan metode tongkat berbicara (talking stick) dalam iringan musik.

Siswa diminta untuk membaca cerpen yang berdurasi 5 menit lalu setelah siswa membacanya siswa dapat menutup teks tersebut agar metode tongkat berbicara (talking stick) dapat diterapkan sebagaimana tongkat diberikan kepada salah satu siswa dan bergulir dari siswa yang satu ke siswa yang lain kepada siswa yang ada disampingnya dengan saling mengoperalihkan tongkat dari tangan ke tangan dengan iringan musik sebagai penentuan pemberhentian tongkat yang bergulir. Ketika musik berhenti berbunyi dan tongkat tersebut harus menjawab pertanyaan yang disampaikan oleh guru kepadanya.

Kegiatan akhir (penutup) peneliti memberikan motivasi kepada siswa untuk belajar dan berlatih di rumah agar keterampilan berbicara dalam menanggapi cerpen dapat meningkat. Guru dan peneliti mengucapkan salam penutup sebelum keluar dari kelas untuk mengakhiri pembelajaran.

Setelah menyelesaikan pelaksanaan tindakan siklus I, pada tahap ini yang menjadi penilaian penting observer (Ibu Usni sebagai guru bidang studi Bahasa Indonesia) selama proses pembelajaran berlangsung di kelas VII-C SMP Negeri 40 Medan pada lembar observasi guru adalah (1) keterampilan peneliti dalam membuka proses pembelajaran, (2) kegiatan yang dilakukan peneliti selama proses pembelajaran pada siklus I, (3) upaya yang dilakukan peneliti yang beraktivitas sebagai guru di kelas VII-C dalam hal pengelolahan kelas pada saat proses pembelajaran dengan menerapkan metode tongkat bebicara (talking stick), (4) keterampilan peneliti dalam menutup pembelajaran, (5) ketepatan peneliti dalam mengatur waktu dari awal hingga akhir pembelajaran di kelas.

Namun pada penelitian ini sebagai bahan penelitian ini sebagai bahan observasi setelah pelaksanaan tindakan siklus I, peneliti akan mendeskripsikan tingkat penguasaan siswa dalam keterampilan berbicara dalam menanggapi cerpen berdasarkan tes yang telah dikerjakan. Pelaksanaan siklus II ini masih menerapkan metode tongkat berbicara (talking stick) dengan segala perbaikan untuk mengatasi masalah yang ada pada siklus I. Siklus II dipersiapkan dan direncanakan lebih matang karena siklus ini merupakan upaya untuk meningkatkan hasil belajar siswa dalam keterampilan berbicara dalam menanggapi cerpen menjadi lebih baik daripada tindakan pembelajaran siklus I. 
Proses pembelajaran dilaksanakan melalui tiga tahap kegiatan pembelajaran, yaitu kegiatan awal, kegiatan inti, kegiatan akhir (penutup). Akan tetapi, ada beberapa kegiatan pembelajaran siklus II yang berbeda dari siklus I. Hal ini dilakukan agar kelemahan-kelemahan atau permasalahan dari siklus I dapat diperbaiki menjadi keberhasilan pembelajaran keterampilan berbicara. Adapun tahapan proses pembelajaran sebagai berikut.

Berdasarkan hasil refleksi dari siklus I, pada kegiatan siklus II ini proses pembelajaran harus lebih diarahkan. Peneliti akan menyiapkan lagu-lagu menarik yang sering didengar atau menjadi favorit anak muda agar siswa tidak bosan dan lebih bersemangat lagi melakukan pembelajaran pada saat penggunaan metode tongkat berbicara (talking stick). Peneliti akan mengulang arahan mengenai proses kerja metode tongkat berbicara (talking stick), memotivasi siswa untuk berani mengungkapkan jawaban dengan kata-kata sendiri tanpa harus takut.

Materi yang akan dibahas pada siklus II ini masih berbicara dalam menanggapi cerpen dengan menerapkan metode tongkat berbicara (talking stick). Adapun indikator keberhasilan siswa yang ingin dicapai pada siklus II ini adalah menemukan dan dapat menjelaskan hal-hal yang menarik dalam cerpen, menemukan unsur intrinsik dan ekstrinsik pada cerpen, dan mengungkapkan kembali cerpen yang telah dibaca dengan menggunakan bahasa sendiri.

Pada kegiatan pembelajaran siklus II peneliti telah mengidentifikasi data yang didapat dari kegiatan yang terlihat dari hasil penilaian tes keterampilan berbicara dalam menanggapi cerpen siswa yang sudah dipaparkan pada tahap observasi sebelumnya. Maka diperoleh hasil analisis kegiatan refleksi pada siklus II bahwa dalam pelaksanaan proses pembelajaran, metode yang digunakan peneliti yang beraktivitas sebagai guru pada setiap tindakan pembelajaran sudah sesuai dengan target yang diharapkan. Pembelajaran keterampilan berbicara dengan penerapan metode tongkat berbicara (talking stick) dalam memperbaiki pembelajaran berbicara dalam menanggapi cerpen siswa kelas VII-C SMP Negeri 40 Medan mendapatkan hasil yang memuaskan sebagaimana keterampilan berbicara siswa mengalami peningkatan.

\section{Simpulan}

Berdasarkan hasil dan pembahasan dalam penelitian ini dapat disimpulkan pembelajaran keterampilan berbicara dalam menanggapi cerpen pada siswa kelas VII-C SMP Negeri 40 Medan sebagai berikut.

1. Kualitas proses pembelajaran keterampilan berbicara dalam menanggapi cerita pendek siswa kelas VII-C SMP Negeri 40 Medan pada prasiklus siswa kurang dalam memahami menanggapi cerpen. Dengan penerapan metode tongkat berbicara (talking stick) yang diberikan pada siklus I dan siklus II dapat meningkatkan hasil belajar siswa. Siswa tidak takut untuk berpendapat, siswa lebih giat dalam membaca, siswa lebih giat untuk mengulang kembali materi yang telah diberikan oleh guru, sehingga hasil dari penerapan metode tongkat berbicara (talking stick) dapat meningkatkan keterampilan berbicara dalam menanggapi cerpen.

2. Kualitas hasil keterampilan berbicara dalam menanggapi cerpen siswa kelas VII-C SMP Negeri 40 Medan, pada prasiklus ketuntasan klasikal 20\%, dan nilai rata-rata siswa mencapai 52,33. Hasil penilaian tes keterampilan berbicara dalam menanggapi cerpen siklus I ketuntasan klasikal 66,67\%, dan nilai rata-rata siswa mencapai 69,5. Pada siklus II metode tongkat berbicara (talking stick) dapat meningkatkan keterampilan berbicara dalam menanggapi cerpen siswa dengan perolehan nilai ratarata siswa yang mencapai 71,67 dan persentase ketuntasan klasikal siswa memperoleh 76,67\%.

3. Peningkatan hasil pembelajaran keterampilan berbicara dalam menanggapi cerpen dengan menerapkan metode tongkat berbicara (talking stick) telah meningkat. Terbukti dari hasil penelitian nilai rata-rata prasiklus 52,33 meningkat kembali nilai rata-rata siswa siklus I 69,5 dan meningkat kembali nilai rata-rata siswa siklus II 71,67. Oleh karena itu, metode tongkat berbicara (talking stick) pada bidang studi Bahasa Indonesia dengan sub pokok pembahasan materi pembelajaran berbicara sangat berperan penting untuk meningkatkan keterampilan berbicara dalam menanggapi cerpen siswa dan mampu memberikan motivasi serta kesenangan siswa dalam proses pembelajaran berbicara dalam menanggapi cerpen yang terkadang membuat siswa jenuh atau bosan sehingga siswa dapat lebih aktif dan lebih bersemangat dalam proses pembelajaran berbicara dalam menanggapi cerpen di kelas VII-C SMP Negeri 40 Medan dengan konsep bermain sambil belajar.

\section{Referensi}


Aliyah, Sri. 2013. PeningkatanKeterampilan Bercerita Menggunakan Media Film Kartun Dengan Metode Talking Stick Pada Siswa Kelas VII C SMP Negeri 1Banjarharjo Brebes. Semarang:UNNES.Tersedia:http://lib.unnes.ac.id/19611/1/2101409015.pdf.[19 Januari 2017].

Anindyarini, Atikah dan Ningsih, Sri. 2008. Bahasa Indonesia untuk SMP kelas VII. Jakarta: Nur Ilmu.

Aqib, Zainal, dan dkk. 2011. Penelitian Tindakan Kelas. Bandung: Yrama Widya.

Arikunto, Suharsimi. 2013. Prosedur Penelitian: Suatu Pendekatan Praktik. Jakarta: Rineka Cipta.

Bungin, Burhan. 2007. Penelitian Kualitatif: Komunikasi, Ekonomi, Kebijakan Publik, dan Ilmu Sosial Lainnya. Jakarta: Prenada Media Group.

Cahyaningsih, Putri Dwi. 2011. Penerapan model talking stick untuk meningkatkan keterampilan berbicara dalam pembelajaran bahasa Indonesia kelas $V$ SDN Jatimulyo 1 kota Malang. Tersedia: http://library.um.ac.id. [19 Januari 2017].

Huda, Miftahul. 2014. Model-model Pengajaran dan Pembelajaran. Yogyakarta: Pustaka Pelajar.

Istarani. 2012. 58 Model Pembelajaran Inovatif. Medan: Media Persada.

Kosasih, E. 2003. Ketatabahasaan dan Kesusastraan Bahasa Indonesia.Bandung: Yrama Widya.

Kurniasih, Imas dan Sani, Berlin. 2015. Model Pembelajaran. Jakarta: Kata Pena.

Moleong, J Lexy. 2016. Metodologi Penelitian Kualitatif. Bandung: Remaja Rosdakarya.

Naiborhu, Ruth Yunita. 2015. "Penerapan Model Pembelajaran Tongkat Berbicara (Talking Stick) Untuk Meningkatkan Keterampilan Menyimak Cerita Rakyat Batubara Pada Siswa Kelas X-2 SMA Dharma Pancasila Medan". Skripsi UNPRI. UNPRI Medan: tidak diterbitkan.

Nasution, Halimahtus Syakdiah. 2013. Penerapan Model Pembelajaran Talking Stick Untuk Meningkatkan Keterampilan Menulis Karangan Argumentasi Di Kelas IV SD Negeri 050785 Pekan Besitang Kab. Langkat. Medan: UNIMED. Tersedia: http://digilib.unimed.ac.id/public. [19 Januari2017].

Purba, Antilan. 2014. Sastra Indonesia Kontemporer. Yogyakarta: Graha Ilmu.

Setiyowati, Ambar. 2009. Peningkatan Kemampuan Menanggapi Cara Pembacaan Cerpen melalui Metode Diskusi Kelompok Kepala Bernomor pada Siswa Kelas VII-A SMP Negeri 18 Semarang: UNNES. Tersedia: http://lib.unnes.ac.id/5402/1/4333A. pdf. [19 Januari 2017].

Shoimin, Aris. 2014. 68 Model Pembelajaran Inovatif dalam Kurikulum 2013.Yogyakarta: Ar Ruzz Media. Subyantoro. 2009. Penelitian Tindakan Kelas. Semarang: Widya Karya.

Sugiyono. 2014. Metode Penelitian Pendidikan: Pendekatan Kuantitatif, Kualitatif, dan R\&D. Bandung: Alfabeta.

Suharma. 2010. Bahasa dan Sastra Indonesia. Jakarta: Yudhistira.

Tantawi, Isma. 2014. Bahasa Indonesia Akademik. Bandung: Citapustaka Media.

Tarigan, Guntur Henry. 2008. Berbicara: Sebagai Suatu Keterampilan Berbahasa. Bandung: Angkasa. 